\title{
The Effect of Performing Reading Activities with Critical Reading Questions on Critical Thinking and Reading Skills
}

\author{
Sefa YILDIRIM ${ }^{1 \rtimes}$ \\ Yusuf SÖYLEMEZ ${ }^{2}$
}

'Agri Ibrahim Cecen University Faculty of Science and Letters, Department of History, Ağrt-Turkey Email:sefa.vildirim25@yandex.com

"Agri Ibrahim Cecen University Faculty of Science and Letters, Department of Turkish Language and Literature, Ağrl-Turkey

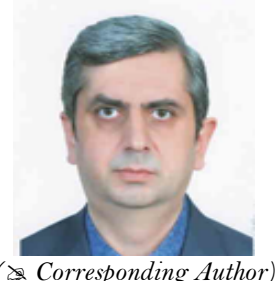

\begin{abstract}
The 21 st century individual should be able to access information and critically evaluate and interpret it. What creates this obligation is the information bombing and political and commercial perception management brought about by virtual networks, the media and globalization. Therefore, critical thinking and its sub-component, critical reading, are becoming more and more important because they are the assistants of the individual who has to distinguish right from wrong and the truth from propaganda in life and texts. The aim of this study is to reveal the effect of performing reading activities with critical reading questions developed by the researchers on critical thinking and reading skills, and to pave the way for further research in this area. Study sample consisted of 232 students of Ağn Ibrahim Çeçen University in the academic year of 20162017. Participants were recruited using random sampling technique. This was a mixed design study. The qualitative dimension of the study was based on a screening model. Data were collected using document review and interview methods, and were analyzed using content analysis. The quantitative dimension of the study was based on a quasi-experimental model. Data were collected using a Critical Thinking Self-Evaluation Form and a Critical Reading Scale (pretest-post-test) before and after a 7-week application. Data were analyzed using a statistical software package. T-test and ANOVA were used for analysis. Results show that reading activities with critical reading questions have a statistically significant effect on students' critical thinking and reading skills. Qualitative data also support these results.
\end{abstract}

Keywords: Critical thinking, Critical reading, Critical reading questions, Critical reading activity

Citation | Sefa YILDIRIM; Yusuf SÖYLEMEZ (2018). The Effect of Performing Reading Activities with Critical Reading Questions on Critical Thinking and Reading Skills. Asian Journal of Education and Training, 4(4): 326-335.

History:

Received: 20 June 2018

Revised: 8 August 2018

Accepted: 30 August 2018

Published: 24. September 2018

Licensed: This work is licensed under a Creative Commons

Attribution 3.0 License (c) $)$ E

Publisher:Asian Online Journal Publishing Group
Contribution/Acknowledgement: Both authors contributed to the conception and design of the study.

Funding: This study received no specific financial support.

Competing Interests: The authors declare that they have no conflict of interests.

Transparency: The authors confirm that the manuscript is an honest, accurate, and transparent account of the study was reported; that no vital features of the study have been omitted; and that any discrepancies from the study as planned have been explained.

Ethical: This study follows all ethical practices during writing.

\section{Contents}

1. Introduction

2. Method

4. Conclusion and Discussion.........333

References. 


\section{Introduction}

A soul that thinks well and right is a stronger discoverer than a sophist.

Sophocles (Cited by, Kranz (1994))

Information is accumulating rapidly and access to it is becoming easier and easier in this constantly changing and developing world. This results in a shift in the direction of education from information carrier to a structure in which information is selected tested and interpreted. Therefore, thinking skills, language and communication skills and reading and comprehension skills are becoming more and more important.

\subsection{Thinking and its Forms}

Referring to "Noesis" in Greek, "cogitare" (cōgitātiō [cogito]) in Latin, "penser" in French and "tefekkür" in Arabic, the concept of "thinking" is defined as the conscious manifestation of mental activities such as comparing, analyzing, synthesizing, suspecting, demanding, feeling, imagining, remembering, free association, connection and form comprehension within the process of learning in philosophical and content (Lewis, 1918; Kabaağaç and Alova, 1995; Peters, 2004; Dogan, 2005; Nişanyan, 2009; Çolak and Demircioğlu, 2010; Çelgin, 2011; Arı, 2013; Cevizci, 2013; Cankaya, 2014; Demirel, 2015; Söylemez, 2015; Budak, 2017; Sarikaya, 2018). Ruggiero also creates a threedimensional thinking classification "reflective, creative, and critical" (Ruggiero, 2017).

Based on the conceptual definitions above, styles of thinking can be classified into several main categories (Akınoğlu and Diriöz, 2007; Güneş, 2012; Doğanay, 2015; Doganay and Tok, 2015; Söylemez, 2015; Sarikaya, 2017; Demirel, 2018):
a) Induction thinking,
b) Deductive thinking,
c) Analytical thinking,
1) Divergent Thinking,
d) Analogous thinking,
e) Systematic thinking,
m) Convergent Thinking,
n) Lateral Thinking,
f) Creative thinking,
o)Transformational Thinking,
g) Clinical thinking,
p) Integrative Thinking,
h) High-level thinking,
q) Hypothetical Thinking,
i) Six thinking hats
r) Global Thinking
j) Reflective thinking,
s) Reflexive Thinking,
t) Omnipotent Thinking,
k) Metacognitive thinking,
u) Iconic Thinking
v) Critical thinking

Another important point is the mental structure and activities of human being. Considering Gardner's statement that mental structures that will build the future are "disciplined, synthesist, creative, respectful and ethical minds" shows that critical thinking is crucial (Gardner, 2006; Sirin, 2012; Judkins, 2017).

\subsection{Critical Thinking and Reading}

"Critical thinking is the art of thinking about your thinking while you are thinking in order to make your thinking better. Critical thinking has three interwoven phases: Analyzing thinking, evaluating thinking and improving thinking."

(Paul and Elder, 2016).

In this context, it can be argued that critical thinking, which is a high-level thinking process, is the art of

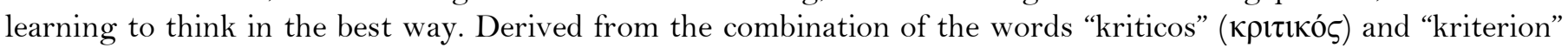

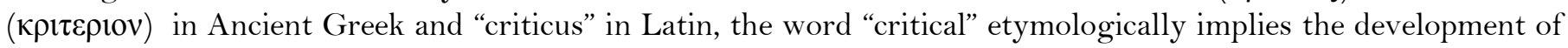
[discerning judgment based on standards] according to Paul and Elder (Lewis, 1918; Kabaağaç and Alova, 1995; Çelgin, 2011; Galetto, 2014; Nosich, 2016; Paul and Elder, 2016).

Some of the features of critical thinking are that it has certain standards, it is reflective, and logical and realistic (Marshall, 2005; Kurnaz, 2007; Kurnaz, 2013; Platon, 2015; Nosich, 2016; Paul and Elder, 2016; Baillargeon, 2017; Budak, 2017; Ruggiero, 2017). According to Paul and Elder (2016) critical thinking consists of three main perspectives: analytical, evaluative and creative. Therefore, critical thinking can be defined as evaluating, thinking objectively, creating standards to determine the true value of something, and using those standards.

Critical reading, which plays a key role in the development of basic language skills, can be defined as making an inference by reasoning, questioning, evaluating, and eventualizing a text and reaching a conclusion (Adall, 2010; Adalı, 2011; Söylemez, 2015; Prosperity, 2016; Scott, 2017). Another key point of critical reading is that it can make significant contributions to the formation of a democratic society.

\subsection{Language and Thinking}

Many scientists from ancient times to the present have expressed that there is a strong connection between "thought" and "language."

To name but a few, Platon and Aristoteles address two important concepts; internal and external speech. Platon defines internal speech, that is, thinking, as "the dialogue of the soul with itself." (Cited by Altinors (2016)).

On the other hand, Augustine asserts that thinking is faster than speaking, and therefore, the task of language is to draw attention to the truth. Descartes also expresses similar views and argues that the inattentive and careless use of language is the greatest obstacle to sound reasoning (Altinors, 2016). Chomsky's remarks on this issue is “...human language should directly reflect the characteristics of human intellectual capacities, that language should be a direct mirror of mind in ways in which other systems of knowledge and belief cannot" (Chomsky, 2018).

Many philosophers and experts view language and speech as the acting out of perceptions and feelings

Many philologists, educators, philosophers and experts are known to put forward many conceptual, functional, linguistic, philological and philosophical judgments, opinions, theories and hypotheses about the functions of language. In this context, it can be stated that language is used as a means of conveying information, raising emotional awareness, putting forward and shaping ideas, ordering, manipulating, directing and explaining objects, 
events and phenomena (Corballis, 2003; Ozdemir, 2013; Dessalles et al., 2014; Söylemez, 2015; Sarikaya, 2016; Baillargeon, 2017).

It can therefore be stated that there is a one-to-one connection between "language" and "thinking", and that the functions that develop depending on these two phenomena are unique to human beings.

It is also important to improve critical listening, reading and visual reading skills in the development of critical thinking. People should develop critical comprehension skills to critically perceive facts, events and expressions while exchanging information, to make accurate, reliable and valid judgments, and to make reliable assessments of the process of acquiring knowledge and information.

\subsection{Concept of Mythology and "A Short History of Myth"}

"We need myths that will help us to identify with all our fellow-beings, not simply with those who belong to our ethnic, national or ideological tribe. We need myths that help us to realize the importance of compassion, which is not always regarded as sufficiently productive or efficient in our pragmatic, rational world. We need myths that help us to create a spiritual attitude, to see beyond our immediate requirements, and enable us to experience a transcendent value that challenges our solipsistic selfishness. We need myths that help us to venerate the earth as sacred once again, instead of merely using it as a 'resource.' This is crucial, because unless there is some kind of spiritual revolution that is able to keep abreast of our technological genius, we will not save our planet" (Armstrong, 2005).

Mythology $[\mu v \theta 0 \lambda o \gamma i ́ \alpha, \alpha \zeta, \eta]$ is a verbal and written form of art. It derives from the combination of the words

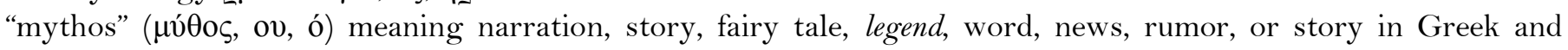

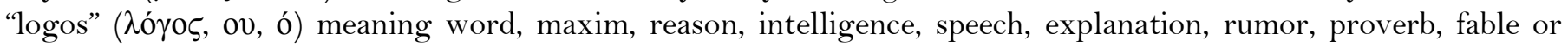
judgment. In addition, some experts have used this word with the meaning of fable [fabul/a-ae], story, fantasy, novel, literature and fiction (Lewis, 1918; Longman-Metro Great English Turkish-Turkish Dictionary, 1993; Kabaağaç and Alova, 1995; Nişanyan, 2009; Öztürk, 2009; Seyidoglu, 2010; Çelgin, 2011; Baillargeon, 2017). When myths first came out, people perceived these literary products as real stories or facts. However, in the last two centuries, modern societies have begun to regard mythological works as falsely believed works of imagination and deformation of reality due to technological advancements and resulting new scientific perspectives. Today, social science experts such as clergy, historians, literati, sociologists, psychologists and ethnologists generally consider mythological works as primitive beliefs, rituals and sacred traditions. In essence, myths or written works can be regarded as literary works of art or knowledge not because they carry scientific facts but because they have direct or indirect influence on human nature, mood, and even on the future prospects of societies.

Perhaps partly serving as a guiding role in seeking for an answer to the mystery of existence and the mystery of life and its truth, mythology can be said to consist of works and rituals bringing back the joy of living and giving solace to those facing death and eternal loss, and feeling frustrated regarding future (Armstrong, 2005; Rosenberg, 2006; McCants, 2012).

In today's scientific culture, God and mythological elements are often not considered much. But it should not be forgotten that the mythological artifacts are the products of people's enormous imagination. Many of the elements that people developed in their imagined world thousands of years ago, such as traveling to the Moon or to Mars, or traveling in space to communicate with God or Gods, or using various plants and materials to combat evil spirits or to heal sicknesses were the foundation of the technology that we have today. In this context, it can be argued that the important benefits of myths are that they carry meaningful knowledge, trigger imagination and provide an opportunity to deeply analyze and synthesize some psychological and sociological problems that an individual or society may encounter (Armstrong, 2005; Rosenberg, 2006; Seyidoglu, 2010; McCants, 2012).

In conclusion, mythology can develop and strengthen the perspectives of people, just like science and social sciences.

Given these characteristics of mythology, it was decided that the book titled "A Short History of Myth" by Armstrong (2005) would be evaluated and included in the application process because it has a suitable topic and knowledge in terms of critical reading. The work consists of 7 chapters and 106 pages. The chapters are:

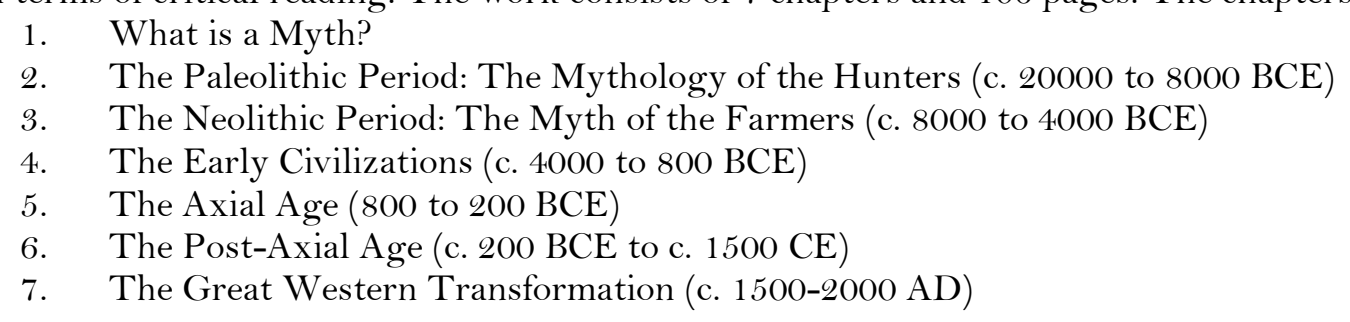

\subsection{Application Process}

A literature review was conducted and the characteristic of critical reading and the scales developed in this area were examined in order to generate critical reading activities. A Critical Reading Activity Questionnaire consisting of 52 items was prepared. Twelve experts were consulted to determine the content validity of the items. The data were analyzed using Lawshe's Content Validity Ratio (CVR) Method and those with low CVR scores were removed from the questionnaire (Lawshe, 1975). 
Table-1. Content Validity Ratio Scores of Critical Reading Activities

\begin{tabular}{|c|c|c|c|c|}
\hline Item & Appropriate & Revise & Remove & CVR \\
\hline 1. & 8 & 1 & 3 & 0.33 \\
\hline 2. & 11 & & 1 & 0.83 \\
\hline 3. & 11 & & 1 & 0.83 \\
\hline 4. & 12 & & & 1.00 \\
\hline 5. & 11 & & 1 & 0.83 \\
\hline 6. & 9 & & 2 & 0.50 \\
\hline 7. & 12 & & & 1.00 \\
\hline 8. & 11 & & 1 & 0.83 \\
\hline 9. & 9 & 1 & 2 & 0.50 \\
\hline 10. & 12 & & & 1.00 \\
\hline 11. & 12 & & & 1.00 \\
\hline 12. & 9 & 1 & 2 & 0.50 \\
\hline 13. & 12 & & & 1.00 \\
\hline 14. & 7 & 1 & 4 & 0.17 \\
\hline 15. & 12 & & & 1.00 \\
\hline 16. & 12 & & & 1.00 \\
\hline 17. & 12 & & & 1.00 \\
\hline 18. & 11 & & 1 & 0.83 \\
\hline 19. & 11 & & 1 & 0.83 \\
\hline 20. & 7 & 3 & 2 & 0.17 \\
\hline 21. & 12 & & & 1.00 \\
\hline 22. & 11 & 1 & & 0.83 \\
\hline 23. & 9 & 1 & 2 & 0.50 \\
\hline 24. & 12 & & & 1.00 \\
\hline 25. & 11 & & 1 & 0.83 \\
\hline 26. & 8 & & 4 & 0.33 \\
\hline 27. & 12 & & & 1.00 \\
\hline 28. & 12 & & & 1.00 \\
\hline 29. & 9 & 2 & 1 & 0.50 \\
\hline 30. & 12 & & & 1.00 \\
\hline 31. & 10 & 2 & & 0.67 \\
\hline 32. & 7 & & 5 & 0.17 \\
\hline 33. & 12 & & & 1.00 \\
\hline 34. & 12 & & & 1.00 \\
\hline 35. & 12 & & & 1.00 \\
\hline 36. & 9 & 1 & 2 & 0.50 \\
\hline 37. & 12 & & & 1.00 \\
\hline 38. & 12 & & & 1.00 \\
\hline 39. & 12 & & & 1.00 \\
\hline 40. & 7 & 2 & 3 & 0.17 \\
\hline 41. & 12 & & & 1.00 \\
\hline 42. & 10 & & 2 & 0.67 \\
\hline 43. & 12 & & & 1.00 \\
\hline 44. & 12 & & & 1.00 \\
\hline 45. & 7 & & 5 & 0.17 \\
\hline 46. & 12 & & & 1.00 \\
\hline 47. & 10 & & 2 & 0.67 \\
\hline 48. & 12 & & & 1.00 \\
\hline 49. & 7 & 1 & 4 & 0.17 \\
\hline 50. & 11 & & 1 & 0.83 \\
\hline 51. & 12 & & & 1.00 \\
\hline 52. & 12 & & & 1.00 \\
\hline
\end{tabular}

In Lawshe's Content Validity Ratio (CVR) Method, the lower limit for 12 experts is .56 (Lawshe, 1975). Table 1 shows that the content validity scores of items, 1, 6, 9, 12, 14, 20, 23, 26, 29, 32, 36, 40, 45 and 49 were lower than $<.56$, and therefore, they were removed from the questionnaire.

Participants (experimental group) were told about the critical reading process consisting of 38 items and were given the questions in written form. The application was performed in a classroom environment and lasted for 5 weeks. 7 experts ( 3 from the field of Turkish Language and Literature, 2 from the field of Turkish education and 2 from the field of history education) were consulted to construct 3 texts to be used in the application. At the end of the application, participants were asked to read "A Short History of Myth" by Armstrong (2005) critically in 2 weeks. An achievement test ( $\mathrm{N}$ 232) was conducted to find out if students read the book, and those with a score below 60 (out of 100) were not included in the study. The statistical data of the achievement test were not included in the study as they were not considered directly relevant to the research topic.

The researchers were not involved in the lecture but they observed and analyzed the answers that students gave to the questions in the course environment ( 5 weeks) and in the application held at home ( 2 weeks). However, students' answers were neither interfered with nor scored. Throughout the process, the instructor who was teaching the course only answered the questions regarding what the items of the questionnaire meant posed by students. 
A pre-test was carried out before the application started. At the end of the 7 th week, a post-test was conducted and the data collection was completed. Data were analyzed and the study was finalized in week 10. The results of the study were shared with the teaching staff and students on request, but no personal data was shared with the third parties.

The central question of the study is as follows:

What is the effect of reading activities with critical reading questions on critical thinking and reading skills?

The sub-questions of the study are as follows:

1. What are students' critical thinking pre-test and post-test results?

2. What are students' critical reading pre-test and post-test results?

3. Do students' critical thinking post-test results differ by gender?

4. Do students' critical reading post-test results differ by gender?

5. Do students' critical thinking post-test results differ by learning style?

6. Do students' critical reading post-test results differ by learning style?

7. Do students' critical thinking post-test results differ by department?

8. Do students' critical reading post-test results differ by department?

9. Do students' critical thinking post-test results differ by high school type?

10. Do students' critical reading post-test results differ by high school type?

11. Do students' critical thinking post-test results differ by age?

12. Do students' critical reading post-test results differ by age?

13. What are students' views of the lecture given using reading activities with critical reading questions?

\section{Method}

The research was based on explanatory mixed design, which is a mixed research method. Mixed design research has two dimensions, quantitative and qualitative. Depending on the objective and structure of research, one of these dimensions may be concentrated on more or repeated more than once. This study concentrated more on quantitative dimension, and qualitative data were collected to support quantitative findings and to accurately describe the process.

Semi-experimental design with pre-test and post-test was used in the quantitative dimension of the study,

Qualitative data were collected using document review and interview techniques in order to explain quantitative data.

\subsection{Population and Sample}

The study population consisted of students of the Departments of History and of Turkish Language and Literature of the faculty of science and literature of Ağrı İbrahim Çeçen University in the academic year of 20162017. The study sample consisted of 232 students (equal number of students from the two departments) recruited using random sampling technique. There were no courses on critical thinking and critical reading offered by the university, therefore, no control group was included in the study. Only pre-test-post-test was applied to the experimental group. It was determined that 169 data on critical thinking and 197 data on critical reading were suitable for evaluation.

\subsection{Data Collection}

Document review and interview techniques were used to collect data in the quantitative dimension of the study. Document review involves the analysis of materials that contain information about facts or phenomena aimed to be investigated (Yıldırım and Şimşek, 2000). A semi-structured interview form developed by researchers was used to find out students' views of the critical reading application. In this technique, the researcher prepares the interview questions in advance, however, he/she provides participants with partial flexibility during the interview and allows questions to be rearranged and discussed (Ekiz, 2013).

The quantitative data of the study were grouped under the headings of critical thinking and critical reading. Data on critical thinking were collected using the critical thinking self-assessment form developed by Kurnaz (2007) while data on critical reading was collected using the critical reading scale developed by Söylemez (2015). The scale developed by Söylemez (2015) was tested at a graduate level and with a sample (N 137) not included in the original study. Cronbach Alpha, Spearman-Brown and Guttmann were found to be $0.89,0.843$ and 0.897 , respectively. These values were close to those of the original scale (Cronbach Alpha 0,854, Spearman-Brown 0,837, Guttmann 0,847). Since all internal consistency coefficients were greater than 0.80 , we can state that the reliability of the Critical Reading Scale was high (Ozer and Dönmez, 2013; Sevim, 2014).

\subsection{Data Analysis}

Quantitative data were analyzed using a statistical software package according to descriptive statistical methods while qualitative data were analyzed using content analysis. The qualitative data were used to describe quantitative data.

\section{Findings}

Two types of qualitative data were found. The first one was concerned with critical reading, which was obtained using document review method, and formed the basis of the experimental part of the research. Based on this information, activity questions about critical reading were generated. 52 activity questions were submitted to the experts. The questions were analyzed using Lawshe's Content Validity Ratio Method, and those with low content validity scores were removed from the questionnaire (Lawshe, 1975). The final version of the questionnaire consisted of 38 questions:

1. What is the significance of the text I read?

2. Can I read this text critically and how ready do I feel about it? 
3. What should I research about the book/what parts of it do I have information about?

4. What information in the book does not agree with my information?

5. What information provided by the book do I need to verify by referring to information sources?

6. What are field-specific concepts in the book? Which of them were explained enough?

7. What is the problem or phenomenon in the text? To what extent did the author explain it?

8. What is the main theme of the text?

9. What are the secondary themes of the text?

10. How has the connection between the main theme and secondary themes been established?

11. What are the cause-and-effect relationships that I have found in the text and have the relationships been established correctly?

12. What are the relationships between the text and other texts and have the relationships been established correctly?

13. Can a relationship be established between the images and the topic of the text?

14. Did I detect anything related to association in the text? If so, what are they?

15. Does the text contain overt/covert commercial/propaganda? If so, what are they?

16. What kind of pattern do I obtain if I classify the information given in the text according to the degree of importance?

17. Do I find the ideas and their bases in the text convincing? Which ones do I not find convincing and how can I be sure about it?

18. Is the text based on truth or fiction?

19. Does the text include solution recommendations? Which ones did I test to be valid and what kind of result did I obtain?

20. What is the main argument of the author of the text? Is it valid?

21. What is the purpose of the author?

22. How has the formal logic on which the text is based been formed?

23. Did I detect an inconsistency in the text?

24. If the text contains a logical fallacy, how did it affect the general structure? What kind of conclusion did it reveal?

25. What are my predictions regarding the text? What are my new predictions besides the ones I found an answer to?

26. How well was I with my predictions and where did I do wrong?

27. What kind of result did I come up with based on the information provided by the text?

28. What are the clear, consistent, logical or unethical information that I have found in the text and and why did the author provide them?

29. Is the information in the text reliable, current and valid?

30. What did I find out in the text about the author's beliefs and prejudices?

31. To what extent is the author's inferences related to the information he/she presents in the text?

32. What information that I obtained from the text do I try to apply in my life?

33. How and where do I share what I have learned from the text?

34. Who would be interested in what I have learned from the text and how can I construct a text that is relevant to them?

35. Which of the assessments that I have made regarding the text am I not sure of?

36. Did my prejudices and prior knowledge have a negative effect on my assessments regarding the text?

37. Did I evaluate the text objectively?

38. What mistakes did I make when making an assessment and how did they affect my inferences?

The second type of qualitative data was collected using a semi-structured form. It was divided into sub-themes.

1. Have you ever participated in this kind of activity before?

$95 \%$ of participants stated that they had never had a similar lecture before while $5 \%$ think that they had a similar lecture before.

$\mathrm{P}$ (participant) 21 stated "I have read looking for answers to pre-determined questions before" while P 123 stated "I have had lectures involving activities before." P 85 “once our teacher showed us a movie and asked us to criticize the negative parts of it." Although participants had similar lectures, they did not have a lecture systematically concentrated on thinking skills and searching for answers to questions and aimed at understanding and analyzing any kind of text.

2. Have you ever had a lesson in high school or college involving critical thinking or critical reading? Although $1 \%$ and $7 \%$ of participants stated that they had a lecture involving critical thinking or critical reading in high school and college, respectively, they did not give any explanatory information.

3. What were the challenges of the activities?

Almost all participants stated that they had a hard time during the process, which was personally observed by the researchers and the lecturers as well. The thematic classification of the challenges for participants was Questions and answers, Evaluation, Text Analysis, Author and Time. Participants had difficulty understanding the questions (32\%) in the Questions and answers section mainly because they had not had been asked similar questions before (81\%). Finding the right answer (77\%) and being sure of the answer $(24 \%)$ were the other two challenges for participants. Some participants read the text a few times to overcome this problem $(65 \%)$ while some others gave up thinking that they would not be able to accomplish the task (3\%).

In the Evaluation section, participants stated that they had difficulty establishing evaluation criteria (57\%), identifying their own evaluation mistakes (14\%) and making sure of their evaluations (38\%). This shows that the students did not make frequent evaluations and that even if they did, they did not use some certain criteria and did not control the process. 
In the Text Analysis section, participants stated that they had difficulty revealing the general meaning of the text (22\%) and detecting the problems in the text (43\%). Most participants (61\%) stated that they especially had difficulty in terms of intertextuality.

In the Author section, participants stated that they had difficulty understanding the purpose of the author $(32 \%)$ and confirming the evidence he/she provided (19\%).

In the Time section, participants stated that they had difficulty in time management (71\%). It may be due to the fact that they were not accustomed to the process and had to read the text over and over again.

4. What do you think are the effects of the lecture on your thinking system?

Participants stated that the lecture helped them raise their awareness on approaching a subject systematically (41\%), seeing through the deep structure of a text (67\%), recognizing a problem and producing a solution (49\%), questioning information (87\%) and breaking down prejudices (39\%).

Quantitative data were analyzed using a statistical software package.

Table-2. Comparison of Critical Thinking Pre-Test and Post-Test Scores

\begin{tabular}{l|l|l|l|l}
\hline & Mean & N & t & p \\
\hline Critical thinking pre-test & 73.66 & 169 & 3.190 & .002 \\
\hline Critical thinking post-test & 78.21 & 169 & & \\
\hline Source: Calculated from the primary data.
\end{tabular}

T-test shows a statistically significant difference between pre-test and post-test mean scores of participants $(\mathrm{t}=$ $3.190 ; \mathrm{p}=.002<.05)$ in favor of the post-test, indicating that there was a significant increase in participants' postapplication critical thinking scores.

Table-3. Comparison of Critical Reading Pre-Test and Post-Test Scores

\begin{tabular}{l|l|l|l|l}
\hline \multicolumn{5}{c}{ Table-3. Comparison of Critical Reading Pre-Test and Post-Test Scores } \\
\hline Critical reading pre-test & Mean & N & t & p \\
\hline Critical reading post-test & 86.08 & 197 & 2.272 & .024 \\
\hline Source: Calculated from the primary data. & 89.91 & 197 & & \\
\hline
\end{tabular}

T-test shows a statistically significant difference between pre-test and post-test mean scores of participants $(\mathrm{t}=$ $2.272 ; \mathrm{p}=.024<.05)$ in favor of the post-test, indicating that there was a significant increase in participants' postapplication critical reading scores.

Participants' statement that the lecture helped them raise their awareness on approaching a subject systematically (41\%), seeing through the deep structure of a text (67\%), recognizing a problem and producing a solution (49\%), questioning information (87\%) and breaking down prejudices (39\%) also confirms the increase in critical thinking and critical reading post-test scores. P 68 stated "Apparently I used to believe everything I saw on social media without questioning it. From now on, I will evaluate every information according to what I have learned in this lecture." $\mathrm{P}$ 128 stated "I understand that judging people and ideas by criteria rather than by prejudices will yield a more accurate result. Let us not let our prejudices blind us!" P 17 stated "Every text has a visible and invisible meaning that I have to figure out, and I realized that many truths come out of it when I figure it out." Participants' statements show that they have recognized the importance of critical reading and therefore critical thinking skills and that they have developed them to some extent. Given the fact that an important feature of critical thinking is to put it into practice and to turn it into a habit, participants' statements become more meaningful.

Table-4. Comparison of Critical Thinking and Critical Reading Scores by Gender

\begin{tabular}{l|l|l|l|l|l}
\hline & Gender & N & Mean & t & p \\
\hline Critical thinking & Male & 82 & 77.41 & .671 & .503 \\
\hline & Female & 87 & 79.01 & & \\
\hline Critical reading & Male & 105 & 89.66 & .219 & .847 \\
\hline & Female & 92 & 90.16 & & \\
\hline
\end{tabular}

Source: Calculated from the primary data.

There is a statistically significant difference in neither critical thinking $(\mathrm{t}=.671 ; \mathrm{p}=.503>.05)$ nor critical reading $(t=.219 ; \mathrm{p}=.847>.05)$ mean scores between male and female participants, indicating that critical thinking and critical reading skills do not differ by gender.

$\mathrm{P} 70$ stated "I want to be a mother in the future and I think it is my job to teach my kids to question and understand life and to ask questions." P 8 stated "I think that girls as well as boys should develop this skill because only then can we build a good society." P 161 stated "I believe that parents should teach their children not to believe everything they hear. That is what I will do, but of course first I have to improve myself." Participants' statements show that they do not take a sexist view on this matter. The lack of a statistically significant difference in post-test scores between male and female participants indicates that not only students in coeducation system but also individuals can develop critical thinking and reading skills.

Table-5. Comparison of Critical Thinking and Reading Scores by Learning Style

\begin{tabular}{l|l|l|l|l|l}
\hline & Learning Style & $\mathbf{N}$ & Mean & t & p \\
\hline Critical thinking & Formal & 93 & 80.31 & 1.939 & .054 \\
\hline & Evening & 76 & 76.11 & & \\
\hline Critical reading & Formal & 99 & 91.32 & 1.402 & .163 \\
\hline & Evening & 98 & 88.50 & & \\
\hline
\end{tabular}

Source: Calculated from the primary data. 
There is a statistically significant difference in the mean scores of neither critical thinking $(t=1,939 ; \mathrm{p}=.054>$ $.05)$ nor critical reading $(\mathrm{t}=1.402 ; \mathrm{p}=.163>.05)$ between participants receiving formal education and those receiving evening education, indicating that critical thinking and critical reading skills do not differ by learning style even though there is a difference in university admission scores between students receiving formal education and those receiving evening education.

Table-6. Comparison of Critical Thinking and Reading Scores by Department

\begin{tabular}{l|l|l|l|l|l}
\hline & Department & N & Mean & t & p \\
\hline Critical thinking & Department of Turkish Language and Literature & 89 & 79.22 & .002 & .963 \\
\hline & Department of History & 80 & 77.20 & & \\
\hline & Total & 169 & 78.21 & & \\
\hline Critical reading & Department of Turkish Language and Literature & 98 & 91.41 & 1.378 & .242 \\
\hline & Department of History & 99 & 88.41 & & \\
\hline & Total & 197 & 89.91 & & \\
\hline
\end{tabular}

Although the mean critical thinking and critical reading scores of Turkish language and literature students are higher than those of history students, there is a statistically significant difference in the mean scores of neither critical thinking ( $\mathrm{t}=.002 ; \mathrm{p}=.963>.05)$ nor critical reading $(\mathrm{t}=1,378 ; \mathrm{p}=.242>.05)$ between them.

P 33 stated "A literary teacher should be able to teach how to read between the lines of a text." P 98 stated "I now believe that I should learn to judge historical events accurately and without prejudgment to become a good history teacher. If I can ask the right questions, my students can find the right answers." P 2 stated "This is the first time I have tried to determine the purpose of an author and look for consistency and reliability in his texts. from now on, I will do this all the time and I will teach this to my students as well." These statements show that literary and history students have a positive attitude towards this matter. The lack of statistically significant difference in post-test scores between literary and history students indicates that they all can develop critical thinking and reading skills. However, both departments are in the field of social sciences, therefore, we cannot generalize this finding to other fields and departments.

ANOVA test results show no statistically significant difference in the mean scores of critical thinking $(\mathrm{F}=1,400 ; \mathrm{p}=.245>.05)$ and critical reading $(\mathrm{F}=1,017 ; \mathrm{p}=.387>.05)$ between participants who graduated from Anatolian, vocational, regular and religious vocational high schools, which may be due to the fact that even though those schools have different curricula, the education they offer is based on similar principles.

Table-7. Comparison of Critical Thinking and Critical Reading Scores by High School

\begin{tabular}{l|l|l|l|l|l}
\hline & High School & N & Mean & F & p \\
\hline Critical thinking & Anatolian High School & 56 & 80.32 & 1.400 & .245 \\
\hline & Vocational High School & 30 & 78.20 & & \\
\hline & Regular High School & 62 & 79.11 & & \\
\hline & Religious Vocational High School & 21 & 75.21 & & \\
\hline & Total & 169 & 78.21 & & .387 \\
\hline & Anatolian High School & 66 & 93.71 & 1.017 & \\
\hline & Vocational High School & 34 & 87.47 & & \\
\hline & Regular High School & 72 & 90.76 & & \\
\hline & Religious Vocational High School & 25 & 87.70 & & \\
\hline Source: Calculated from the primary data. & 197 & 89.67 & & \\
& Total & &
\end{tabular}

Source: Calculated from the primary data.

95\% of participants stated that they had never had a similar lecture before while $99 \%$ stated that they had not had a lesson on critical thinking or critical reading in high school, which may account for why there was no statistically significant difference in post-test scores between participants in terms of high schools from which they graduated.

Table-8. Comparison of Critical Thinking and Critical Reading Scores by Age

\begin{tabular}{l|l|l|l|l|l}
\hline & Age & N & Mean & F & p \\
\hline Critical thinking & $17-25$ & 164 & 65.13 & 3.374 & .025 \\
\hline & $26-34$ & 3 & 73.43 & & \\
\hline & $35-43$ & 2 & 96.07 & & \\
\hline & Total & 169 & 78.21 & & \\
\hline Critical reading & $17-25$ & 187 & 94.63 & 1.348 & .263 \\
\hline & $26-34$ & 6 & 99.32 & & \\
\hline & $35-43$ & 4 & 75.78 & & \\
\hline & Total & 197 & 89.91 & & \\
\hline
\end{tabular}

Source: Calculated from the primary data.

ANOVA test results show that the mean critical thinking scores of participants differ by age $(\mathrm{F}=3.374 ; \mathrm{p}=$ $.025<.05)$. According to Post Hoc analysis, there is a statistically significant difference in the mean critical thinking scores between 17-25 and 35-43 age groups, and 26-34 and 35-43 age groups. This indicates that critical thinking skills improve with age. However, the mean critical reading scores of participants do not differ by age $(\mathrm{F}=$ $1.348 ; \mathrm{p}=.263>.05$ ), suggesting that the sample is homogeneous in terms of learning critical reading skills.

\section{Conclusion and Discussion}

While the modern world has removed the burden of carrying knowledge from the shoulders of people to machines and virtual networks, it has brought with it the necessity of advancing our comprehension and thinking 
skills to the highest level. Critical reading, which is one of the sub-dimensions of critical thinking, is also an important high-level thinking skill. For this reason, this experimental study was carried out

Since it was not appropriate to provide students with all critical reading steps at once, they were translated into questions for students to look for answers. These questions, 3 texts and 1 book were determined based on expert opinion. Critical Thinking Self-Evaluation Form and Critical Reading Scale were applied as pre-test before application ( 7 weeks) and post-test after 7 weeks. At the end of the application, a semi-structured interview form was used to elicit information on participants' views.

The result of the analysis of the findings showed that there was a statistically significant difference in critical thinking and reading scores in favor of the post-test, indicating that reading activities with critical reading questions yielded results similar to those reported by previous studies and that those activities had a positive effect on critical thinking and reading skills (Özensoy, 2011; Topçuoğlu and Sever, 2013). Participants are of the opinion that lessons involving reading activities with critical reading questions have a positive effect especially on their awareness on approaching a subject systematically, seeing through the deep structure of a text, recognizing a problem and producing a solution, questioning information and breaking down prejudices.

Participants experienced some difficulties during the lessons, which was not only observed by the researchers but also stated by the participants themselves. The subjects that they had difficulties were: Understanding the questions and finding the correct answers, Evaluation, Text analysis, Determining the purpose of the author, Confirming the evidence he/she provides, and Time management.

Similar to the results of previous studies, the mean critical thinking and reading scores of participants did not differ by gender, type of high school and department (Akar, 2007; Gulveren, 2007; Hamic, 2007; Zayif, 2008; Şen, 2009; Topçuoğlu and Sever, 2013; Özdemir, 2017). There are, however, some studies reporting that female students' critical thinking is better than that of male students (Yildirim, 2005; Gulveren, 2007; Zayif, 2008). The mean critical thinking scores of participants differed only by age. However, no qualitative data was available to explain this. Akar (2007); Kurim (2002) and Gulveren (2007) reported that age was a factor, however, younger participants were found to have higher critical thinking scores than older participants in this study.

In conclusion, the reading activities were found to be effective in developing critical thinking and reading skills. The lack of a statistically significant difference in post-test scores in terms of gender, department and high school is consistent with the results of many studies. The lack of a statistically significant difference in post-test critical reading scores between age groups is also consistent with the results of other studies while the statistically significant difference in post-test critical thinking scores between age groups in favor of older age groups is inconsistent with the results of other studies.

\section{References}

Adalı, O., 2010. Interactive and critical reading techniques. Istanbul-Turkey: Toroslu Library. pp: 9.

Adal, O., 2011 . Understand and tell. Istanbul-Turkey: Pan Publishing. pp: 21-33.

Akar, Ü., 2007. The relationship between teacher candidates' scientific process skills and critical thinking skills levels. Unpublished Master's Thesis. Afyon Kocatepe University Social Sciences Institute, Afyon.

Akınoğlu, O. and U. Diriöz, 2007. Development of critical and creative thinking in history teaching. Ankara-Turkey: Pegem Publishing. pp: 15

Altinors, A., 2016. Philosophy of language in 50 sources. Istanbul-Turkey: Science and Future Library-30.

Arı, A., 2013. Revised bloom, SOLO, fink, dettmer taxonomies and international recognition situations in the cognitive domain classification. Uşak University Journal of Social Sciences, 6(2): 259-290.

Armstrong, K., 2005. A short history of myth. Istanbul-Turkey: Dilek Şendil, Central Bookstore. pp: 93.

Baillargeon, N., 2017. A critical thinking guide in the light of the mind and science, original title: A short course in intellectual self-defense, trans: Ibrahim Yildiz. Istanbul-Turkey: Footnote Publications. pp: 9-14.

Budak, S., 2017. Psychology dictionary. Ankara: Science and Art Publications. pp: 236, 250.

Cankaya, A., 2014. Decisions on nous and noesis concepts in Aristotle. Cogito. (Aristotle). Istanbul-Turkey: YKY.YAPI Credit Publications, 77.

Çelgin, G., 2011. Ancient Greek-Turkish dictionary. Istanbul: Kabalcı. pp: 385, 403.

Cevizci, A., 2013. Paradigm philosophy dictionary. Istanbul: Paradigma PublicationsPress.

Chomsky, N., 2018. Language and mind, trans: Big, A \& Aysever, R.L. Ankara: BilgeSu Publications.

Çolak, K. and H.I. Demircioğlu, 2010. Classification of bloom taxonomy in terms of cognitive domain level of exam questions of history class. National Education, 40(187): 160-170.

Corballis, M.C., 2003. From hand to mouth: The origins of language. USA: Princeton University Press. pp: 12.

Demirel, N., 2015. Continuity of programs involving professional subjects in non-functional programs that are not based on the needs of determining the needs of scientific methodological motivation. International Social Research Journal, 8(36): 702-709.

Demirel, N.I.., 2018. The viewpoints of the teacher candidates about the terms of sufficiency of education programme and education environment. Universal Journal of Educational Research, 6(5): 1077-1083. DOI DOI: 10.13189/ujer.2018.060529.

Dessalles, J., P. Picq and B. Victorri, 2014. Origins of Dilin, [Original title: The origins of language], (Atakan Altınörs, Trans.). İstasnbul: Bilge Culture Art. pp: 73, 77, 102.

Dogan, A., 2005. Ottoman Turkish dictionary. Ankara: Akçă̆ Publications. pp: 665.

Doğanay, A., 2015. Instruction of higher thinking skills teaching principles and methods, chapter: 7th Edn. Ankara: Ahmet Dogana y, Pegem Academy. pp: 303-356.

Doganay, A. and Ş. Tok, 2015. Contemporary approaches in teaching, principles and methods of teaching, department. 6th Edn., Ankara: Ahmet Doğanay.Pegem Academy. pp: 239-301.

Ekiz, D., 2013. Scientific research methods. Ankara: Memorable.

Galetto, F., 2014. Angelo Conference Proceedings 15th Toulon- Verona Conference "Exellence in Services" College of Management Academic Studies, Rishon Lezion, Israel, 3-4 September 2014. pp: 377-388.

Gardner, H., 2006. Five minds for the future. USA: Harvard Business Press. pp: 9-29.

Gulveren, H., 2007. Critical thinking skills of the faculty of education students and critical thinking factors affecting these skills. Unpublished Doctoral Thesis. Dokuz Eylül University Educational Sciences Institute, İzmir.

Güneş, F., 2012. Improving the thinking skills of students. Journal of Turkology Research, 32(2): 127-146.

Hamic, S., 2007. Arrangement of critical thinking strength levels of mathematics teaching undergraduates according to some variables. Unpublished Master's Thesis. Dokuz Eylül University Educational Sciences Institute, İzmir.

Judkins, R., 2017. The art of creative thinking. Trans: Sevinç Seyla Tezcan. Istanbul-Turkey: Pegasus Publications.

Kabaağaç, S. and E. Alova, 1995. Latin dictionary. Istanbul: Social Publications. pp: 94, 141.

Kranz, W., 1994. Ancient philosophy, texts and explanations (Fr.97). Suad Y. Baydur. Istanbul: Social Publications. pp: 223. 
Kurim, D., 2002. Critical thinking power of teacher candidates. Unpublished Master's Thesis). Anadolu University Educational Sciences Institute, Eskişehir.

Kurnaz, A., 2007. The impact of the skill and content based thinking teaching on the critical thinking skills, attitudes and attitudes of the students in the fifth grade primary school social studies course. PhD. Dissertation, Department of Educational Sciences Supervisor: Assoc. Professor Ali Murat SÜNBÜL. T. C. Selcuk University. Social Sciences Institute. Department of Educational Sciences Department of Education and Teaching. Turkey. pp: 6179 .

Kurnaz, A., 2013. Critical thinking teaching activities, planning-implementation and evaluation. Konya-Turkey: Eğitim Yayınevi. pp: 7, 193.

Lawshe, C.H., 1975. A quantitative approach to content validity. Personnel Psychology, 28(4): 563-575.

Lewis, C.T., 1918. An elementary Latin dictionary. New York, Cincinnati, Chicago: American Book Company. pp: $138,197$.

Longman-Metro Great English Turkish-Turkish Dictionary, 1993. United Kingdom: Longman Group UK Limited and Metro Book Publishing Marketing Inc.

Marshall, G., 2005. Dictionary of sociology, original tittle: A dictionary of sociology, Trans: Ankara: Osman Akınhay \& Derya Kömürcü. Ankara-Turkey: Publications of Science and Art

McCants, F.W., 2012. Myths of culture, creating the Gods, Inventing the nations, original title: Founding Gods, inventing nations, conquest and culture myths from antiquity to Islam. Istanbul-Turkey: Merve Tabur, Ithaki Publications.

Nişanyan, S., 2009. Pedigree of words, etymological dictionary of contemporary Turkic. Istanbul: Everest Publications. pp: 149, 414, 612.

Nosich, M.G., 2016. Critical thinking and interdisciplinary, master of critical thinking, original title: Trans learning to think things through, a guide to critical thinking across the curriculum. Istanbul-Turkey: Birsel Aybek, Ani Publishing. pp: 15, 3.

Ozdemir, E., 2013. Critical reading. Istanbul-Turkey: Bilgi Publisher. pp: 19.

Özdemir, S., 2017. Critical reading self sufficiency of middle school students. Mehmet Akif Ersoy University Journal of Educational Sciences Institute, $5(7): 41-55$.

Özensoy, A.U., 2011. The effect of the social studies course prepared by critical reading to the critical thinking skill. Journal of Mersin University Education Faculty, 7(2): 13-25.

Ozer, N. and B. Dönmez, 2013. Safety cameras and school safety: A scale development work. International Periodical For Languages, Literature and History of Turkish or Turkic, $8(3): 437-448$.

Öztürk, Ö., 2009. Folklore and mythology dictionary. Ankara: Phoenix Publications. pp: 5.

Paul, R. and L. Elder, 2016. Critical thinking, tools for taking charge of your learning and your life trans. Esra Aslan \& Gamze Sart. AnkaraTurkey: Nobel Publications.

Peters, E.F., 2004. Greek philosophical terms / a historical reading. Istanbul-Turkey: Paradigma Publishing. pp: 228.

Platon, 2015. The advocacy of socrates, [original title: Socrates' apex], (Furkan Akderin, Trans.). Istanbul-Turkey: Say Publishing.

Prosperity, M., 2016. Critical reading from critical discourse. Ankara: Ani Publishing. pp: 112-117.

Rosenberg, D., 2006. World mythology, anthology of great epic and myths, original title; World mythology, trans: Koray Akten, Erdal Cengiz, Atil Ulaş Duzce, Kudret Emiroğlu, Tuluğ Kenanoglu, Tahir Kocayiğit, Erhan Kuzhan, Bengü Odabaşı. Istanbul-Turkey: Imge Bookstore Publications. pp: 15-26.

Ruggiero, R.V., 2017. Beyond feelings A guide to critical thinking, trans. Cadde Dedeoglu. Istanbul-Turkey: Alfa Publications. pp: 52.

Sarikaya, B., 2016. The effect of structured images according to problem solving steps on writing skills and attitudes of 6 th, 7 th and 8 th grade students with hearing impairment. Atatürk University, Institute of Educational Sciences. (Unpublished PhD Thesis).

Sarikaya, B., 2017. Visual reading in Turkish teaching. Journal of Social Sciences of Muş Alparslan University, 5(3): 779-796.

Sarikaya, B., 2018. The effect of structured images according to problem solving steps on the writing skills of 6 th, 7 th and 8 th grade students with hearing impairment. Asos Journal, 6(70): 57-75.

Scott, W.J., 2017. Critical theory of history: Identities, experiences, policies. Zerrin Yaya. Istanbul-Turkey: Dost Bookstore. pp: 19-41.

Şen, Ü., 2009. Evaluation of Turkish teacher candidates in terms of various variables of their critical thinking attitudes. Journal of the World of Turks / Journal of World of Turks, 1(2): 69-89.

Sevim, O., 2014. Development of the academic ethics scale: Reliability and validity study. Turkish Studies - International Periodical For Languages, Literature and History of Turkish or Turkic, 9(6): 943-957.

Seyidoglu, B., 2010. Research on mythology, texts and analyzes. Erzurum-Turkey: Dergah Publications. pp: 15.

Sirin, H., 2012. Orientations in educational science in the 21 st century, introduction to educational science, Ed: Leyla Küçü kahmet. AnkaraTurkey: Nobel Publications, 9 \& I: 23-50.

Söylemez, Y., 2015. Development of critical essential language skills for middle school students. Unpublished Doctoral Thesis. Ataturk University Educational Sciences Institute. Erzurum.

Topçuoğlu, Ü.F. and A. Sever, 2013. Sense-efficacy perceptions of Turkish teacher candidates' for critical reading. Journal of Language and Literature Education, 2(6): 33-42.

Yıldırım, A. and H. Şimşek, 2000. Qualitative research methods in the social sciences. (Review 2). Ankara: Distinguished.

Yildirim, A.Ç., 2005. An investigation of critical thinking skills of Turkish and Turkish language and literature teachers. Unpublished Master's Thesis. Zonguldak Karaelmas University Institute of Social Sciences, Zonguldak.

Zayif, K., 2008. Critical thinking tendencies of teacher candidates. Unpublished Master's Thesis. Abant Izzet Baysal University Social Sciences Institute, Bolu. 